\title{
The Potential of the Isolated Probiotics Bacterial from Giant Prawns' Digestive Tract (Macrobrachium Rosenbergii, De Man) with 16S rDNA Sequencing Technique
}

\author{
Feliatra*, Dessy Yoswaty, Iesje Lukistyowati, and Wahid Hasyimi \\ Faculty of Fisheries and Marine Sciences University of Riau \\ College of Bina Widya km. 12,5 Pekanbaru \\ *e-mail:feliatra@yahoo.com
}

\begin{abstract}
Feliatra, Dessy Yoswaty, Iesje Lukistyowati, and Wahid Hasyimi. 2014. The Potential of the Isolated Probiotics Bacterial from Giant Prawns' Digestive Tract (Macrobrachium Rosenbergii, De Man) with 16S rDNA Sequencing Technique. Aquacultura Indonesiana, 15 (2) : 57-63. Probiotics is a bacterial product that has the advantage for fish; it is not only for growing but also for covering the bacteria's attack. The aim of the study is to determine the types of candidate bacteria's probiotic of which the digestive tract of giant prawns in Teratak Buluh Pekanbaru, Riau. This research was conducted at the Laboratory of Microbiology and Biotechnology of Fisheries and Marine Sciences faculty, University of Riau, Pekanbaru to get a candidate of Probiotic Bacteria and conduct molecular examination that consists of purification of electrophoresis gel and $16 \mathrm{~S}$ rDNA sequencing at the Institute for Biotechnology Serpong, Tangerang Banten. The method used in this researh was physical, biochemical and molecular test in order to identify the candidate bacteria. The results showed that the are eleven isolates of bacterial are the species Bacillus BDU4 strain from A Bacteria isolates with $99 \%$ homology and 10 isolates of bacterial are bacillus genus because the degree of homology below $97 \%$ and they are considered as the original indonesia's new species probiotic bacteria.
\end{abstract}

Keywords: Bacillus and 16S rDNA; Bacteria; Giant Prawns; Probiotics

\section{Introduction}

Giant Prawn is one type of prawns that has a high economical value and high consumed of Riau people. In Healthy Giant Prawns digestive system was found some bacterias that help to digest food that is not able to be digested by the intestine. The positive effect was given by the most of bacterias relatively small. This condition can be developed and accelerated the growth of Giant Prawns Fishery. Some of these bacterias are producing microbes that can damage the Giant Prawns' disease bacteria.

Disease control strategies in Fishery that was always done and it gave good results is the use of probiotic bacteria. This bacterium is more secure than the use of chemicals, does not accumulate in the food chain, can reduce repeated using in reproduction, the target organism, rarely become resistant to the probiotic agent, can do the controler with other material and do pathogen controler on the host and the environment, stimulate Giant Prawns immunity and as agents to improve water quality by reducing pollutants capabilities.

According to Irianto (2003), the product is composed by microbial products or natural feed microscopic, are beneficial and give effect to the increase in the balance of the intestinal microbial. Aquaculture Probiotics has a role in increasing the growth rate, improve the immune system in the bacterial community intestinall changes.

Feliatra et al. (2004) found nine species of bacterias that have the potential as probiotics on the digestive track of Ephinephelus fuscogutatus fishes, they are Lactococcus sp., Carnoacterium sp., Staphylococcus sp., Bacillus sp., Eubacterium sp., Pseudomonas sp., Lactobacillus sp., Micrococcus sp., and Bifidobacterium sp. Because they have resilience at $\mathrm{pH} 2$, which is main indicator as probiotic bacteria.

Bacteria from genus of Bacillus, Bifidobacteri, Pseudomonas, Lactobacillus, and Micrococcus has been proven as beneficial bacteria and can live both inside and outside the body as normal Flora on organisms, while others are suspected of bacteria as benefecial probiotic bacteria. According to Yulvizar (2013), there are 5 isolates potential as probiotics from the stomach and intestines of Rastrelliger sp. These isolates consisted of three general of bacterias. They are Micrococcus, Staphylococcus and Bacillus then one bacteria species, it is Hafnia alvei.

Based on these findings, the study was conducted to obtain BAL from the digestive tract of Giant prawns (Macrobrachium rosenbergii). The findings is charecterized by phenotypic and 
genotypic (morphological observation, physiological properties and biochemical tests) and Genotip was analized based on sequence of $16 \mathrm{~S}$ rDNA by using Polimirase Chain Reaction (PCR) and nucleotide sequence was analized based on the program Basic Local Alignment Search Tool (BLAST).

\section{Materials and Methods}

Sample of this study is Giant Prawns that has size $15-30 \mathrm{~cm}$ from Teratak Buluh, Riau. Digestive tarck of Giant prawns is taken then it is smoothed by using a mortal and diluted by using physiological condensation with $\mathrm{pH} 2$. Then the samples were grown on NA medium (Nutrient Agar) with methods for 24 hours at a temperature of $28^{\circ} \mathrm{C}$. The growing Bacteria was purified to obtain a pure or single bacteria and done the physics and biochemistry test. Biochemical tests was done likr observation of colony characteristics, observation of cell -type coupling, test Gram stain, catalase test, motility test, methyl red test, test growth at different temperatures, the test $\mathrm{O} / \mathrm{F}$, indol test, citrate test, test the use of sugar, and test sulfide (H2S). Then they were done molecular identification.

\section{Molecular Test}

Probiotics bacteria were mixed again in LB liquid medium (Luria - Bertani medium) for 4 $\mathrm{mL}$ in a test tube. Then they were incubated at $37^{\circ} \mathrm{C}$ for 24 hours. The result was transferred into a $1.5 \mathrm{~mL}$ tube and then centrifuged at a speed of $13,000 \mathrm{rpm}$ at a temperature of $4^{\circ} \mathrm{C}$ for 2 minutes. Then its supernatant is discarded to the remaining pellets. Then pellets were added with $400 \mu \mathrm{L}$ of I cold condensation. After that, they were homogenized by using a vortex and were added $20 \mu \mathrm{L}$ of lysozym and inverted from 3 to 5 times and incubated at $-40^{\circ} \mathrm{C}$ for 10 minutes. After that, added $10 \%$ SDS as much as $550 \mu \mathrm{L}$, mixed by $20 \mathrm{rpm}$ speed for 10 minutes. Then added $550 \mu \mathrm{L}$ condensation of P: C: I (25: 24 : $1)$ in the cold condition. Mixed by a speed of 20 rpm for 10 minutes. Then they were mixed by $700 \mathrm{rpm}$ speed at $4^{\circ} \mathrm{C}$ for 10 minutes. In addition, Moved the top of supernatan and taken the bottom of supernatan transferred into a sterile 1.5 $\mathrm{mL}$ tube. Then added $550 \mu \mathrm{L}$ condensation of $\mathrm{P}$ : C: I $(25: 24: 1)$ in the cold condition. Mixed by a speed of $20 \mathrm{rpm}$ for 10 minutes. Then they were mixed by $700 \mathrm{rpm}$ speed at $4{ }^{\circ} \mathrm{C}$ for 10 minutes. In addition, Moved the top of supernatan and taken the bottom of supernatan transferred into a sterile $1.5 \mathrm{~mL}$ tube. Then added $40 \%$ of the supernatant volume of $3 \mathrm{M}$ sodium acetate solution ( $\mathrm{CH} 3 \mathrm{COONa}$ ), and also added $2 \mathrm{x}$ the volume of supernatant $99 \%$ alcohol in a cold condition. After that, they were homogenized and incubated at $-20^{\circ} \mathrm{C}$ for 30 minutes. After 30 minutes, they were centrifuged by a speed of $13,000 \mathrm{rpm}$ at a temperature of $4^{\circ} \mathrm{C}$ for 10 minutes. Then the supernatant was discarded to get pellets, and done the addition of $1000 \mu \mathrm{L}$ condensation of ethanol in the cold condition. After that, they were centrifuged at a speed of $13,000 \mathrm{rpm}$ for 10 minutes at a temperature of $4^{\circ} \mathrm{C}$. Supernatant was discarded to get pellets. After that, they were dried up and added $40 \mu \mathrm{L}$ of TE buffer $\mathrm{pH} 8$ and $2.5 \mu \mathrm{L}$ of RNase condensation. Then they were homogenized by using a vortex and incubated at $370 \mathrm{C}$ for 1 hour. Bacterial DNA is ready to use and if they were not used can be stored at a temperature of $-4^{\circ} \mathrm{C}$. Electrophoresis was done to prove the single bacteri.

The PCR test is done by mixing the DNA of each candidate probiotic bacteria by using $16 \mathrm{~S}$ as much as $32 \mu \mathrm{L}$ that consist of $23 \mu \mathrm{L}$ ddH2O, 4 $\mu \mathrm{L}$ 10x Taq Buffer Dream, $0.5 \mu \mathrm{L}$ dNTP mix 12 $\mathrm{mm}$, universal primers; $2 \mu \mathrm{L} 24 \mathrm{~F}$ (5'AGAGTTTGATCCTGGCT-3') and $0.5 \mu \mathrm{L}$ 1541R (5'AAGGAGGTGATCCAGCCGCA- 3'). Then they were homogenized by shaking by hand. Then each candidate tube was inserted 8 $\mu \mathrm{L}$ DNA bacterial candidate. Then eppendrof micro tube was inserted into the DNA engine thermal cycler by following 16S PCR program: 1 cycle at a temperature of $94^{\circ} \mathrm{C}$ for $2 \mathrm{~min}$ (denaturation), followed by 30 cycles with a temperature of $50^{\circ} \mathrm{C}$ for $40 \mathrm{sec}$ (annealing), DNA synthesised at temperature of $72^{\circ} \mathrm{C}$ for 1 minute and a temperature of $94^{\circ} \mathrm{C}$ for 1 minute. In the last cycle, synthesised at a temperature of $72{ }^{\circ} \mathrm{C}$ for $5 \mathrm{~min}$ and stored at $40 \mathrm{C}$.

\section{DNA Purification}

$1.5 \mathrm{~mL}$ Cemichal tubes were weighed first before used. The Agarose gel which is containing probiotic bacteria candidate DNA fragment is cutted and inserted into the tube which has been weighed. After that Tube was weighed again. Their ddifferences of weight was calculated. Then added $500 \mathrm{~mL}$ xpdf buffer on samples and mixed by using divorteks and incubated at $55-600 \mathrm{C}$ for $10-15$ minutes until dissolves. After the gel is dissolved, the sample was cooled like room temperature. XPDF column 
was placed in $2 \mathrm{~mL}$ tubes. The sample was transferred to column of XPDF (over than 700 $\mu \mathrm{L}$ ), and then centrifuged at a speed of 13,000 rpm for 1 minute to obtain pellets of the samples.

Results of screening from tube of $2 \mathrm{~mL}$ were placed back on XPDF colomn. $750 \mu \mathrm{L}$ wash buffer was added and centrifuged at 13,000 rpm for 1 minute. The condensation was flushed out of the tube $2 \mathrm{~mL}$, then placed back on the field XPDF $2 \mathrm{~mL}$ tube. The they were centrifuged at a speed of $13,000 \mathrm{rpm}$ for 3 minutes. XPDF column was transferred to a $1.5 \mathrm{~mL}$ tube. DNA result was eluted by adding $40 \mu \mathrm{L}$ elution buffer in the middle of the column XPDF membrane, incubated for 2 minutes and centrifuged at a speed of 13,000 rpm for 3 minutes and then the DNA was stored at $4^{\circ} \mathrm{C}$.

\section{Sequencing and BLAST Analysis}

The result of DNA Purified was sequenced using the ABI 3010 XL Genetic Analyzer Applied Biosystems. In sequencing stage, all tube are containing $0.2 \mathrm{~mL}$ purified samples of the DNA inserted into the ABI 3010
XL Genetic Analyzer Applied Biosystems. Sequencing was carried out by using a computer. Sequencing was done at the Institute for Biotechnology Serpong, Tangerang, Banten and analized by BLAST (Basic Local Alignment Search Toll), which is accessed in website http://www.nebi.nih.gov/blast.

\section{Results and Discussion}

The research result of Probiotic Giant prawns Candidate was derived from the digestive track Giant prawns are 11 isolates. The physical and biochemical tests found out probiotic candidates that has characteristics as shown in Table 1.

Eleven potential bacterial strains of probiotic bacteria are found that have different characteristics from each other, so the findings are variant. Six of them are gram positive and five are gram negative. They are unmotil or unmoving bacteries while the other bacteries have the variant charecteristics (Table 1).

Table 1. The Observation result of Morphology and Biochemical on potential bacterial

\begin{tabular}{|c|c|c|c|c|c|c|c|c|c|c|c|}
\hline Isolat & A & B & $\mathrm{C}$ & $\mathrm{D}$ & $\mathrm{E}$ & $\mathrm{F}$ & G & $\mathrm{H}$ & I & $\mathrm{J}$ & $\mathrm{K}$ \\
\hline Type of colony & $\begin{array}{c}\text { Irregular } \\
\text { and } \\
\text { dismenating }\end{array}$ & Cyrcle & Cyrcle & Cyrcle & Cyrcle & Irregular & Irregular & Cyrcle & Irregular & $\begin{array}{l}\text { Berbenang- } \\
\text { benang }\end{array}$ & Irregular \\
\hline Coloni colour & Fade cream & $\begin{array}{l}\text { Dark } \\
\text { cream }\end{array}$ & $\begin{array}{l}\text { Fade } \\
\text { Kream }\end{array}$ & $\begin{array}{l}\text { Fade } \\
\text { Kream }\end{array}$ & $\begin{array}{c}\text { Fade } \\
\text { Kream }\end{array}$ & Fade Cream & $\begin{array}{l}\text { Fade } \\
\text { cream }\end{array}$ & $\begin{array}{l}\text { Yellow } \\
\text { Crream }\end{array}$ & $\begin{array}{l}\text { Dark } \\
\text { cream }\end{array}$ & $\begin{array}{c}\text { Dark } \\
\text { cream }\end{array}$ & $\begin{array}{l}\text { Yellow } \\
\text { cream }\end{array}$ \\
\hline $\begin{array}{c}\text { Type } \\
\text { Penggandengan }\end{array}$ & $\begin{array}{l}\text { Carbol- } \\
\text { fuchsin } \\
\text { stain }\end{array}$ & $\begin{array}{l}\text { Gram } \\
\text { stain }\end{array}$ & $\begin{array}{l}\text { Gram } \\
\text { stain }\end{array}$ & $\begin{array}{l}\text { Gram } \\
\text { stain }\end{array}$ & $\begin{array}{l}\text { Methylene } \\
\text { blue stain }\end{array}$ & $\begin{array}{l}\text { Pappenheim's } \\
\text { stain }\end{array}$ & $\begin{array}{l}\text { Gram } \\
\text { stain }\end{array}$ & $\begin{array}{c}\text { Hiss } \\
\text { capsole } \\
\text { stain }\end{array}$ & $\begin{array}{l}\text { Gram } \\
\text { stain }\end{array}$ & $\begin{array}{l}\text { Carbol- } \\
\text { fuchsin } \\
\text { stain }\end{array}$ & $\begin{array}{c}\text { Gentian } \\
\text { violet } \\
\text { stain }\end{array}$ \\
\hline Gram & + & - & - & - & + & + & + & - & + & - & + \\
\hline Katalase & + & + & - & - & - & - & - & - & - & - & - \\
\hline Motility & - & - & - & - & - & - & - & - & - & - & - \\
\hline $\begin{array}{c}\text { Different } \\
\text { Degree }(28- \\
\left.37^{0} \mathrm{C}\right)\end{array}$ & + & + & + & + & + & + & + & + & + & + & + \\
\hline $\mathrm{O} / \mathrm{F}$ & $\mathrm{O}$ & $\mathrm{O}$ & $\mathrm{O}$ & $\mathrm{O}$ & $\mathrm{O}$ & $\mathrm{O}$ & $\mathrm{O}$ & $\mathrm{O}$ & $\mathrm{O}$ & $\mathrm{O}$ & $\mathrm{O}$ \\
\hline Indol & \pm & + & \pm & \pm & + & \pm & + & \pm & \pm & + & \pm \\
\hline Metil Red & + & + & - & - & + & - & - & - & - & - & + \\
\hline Citrat & - & - & + & + & + & - & - & - & - & - & - \\
\hline Glukosa & + & + & + & + & + & + & + & + & + & + & + \\
\hline Sukrosa & - & + & + & - & - & + & - & - & - & + & + \\
\hline $\mathrm{H}_{2} \mathrm{~S}$ & - & + & - & - & - & - & + & - & - & - & - \\
\hline
\end{tabular}


Further, molecular identification test showed the results of long- bases on each candidate's diverse bacterial isolates and formed bands with a molecular weight $1500-2000 \mathrm{bp}$. For more details of purification results can be seen in Figure 1.

After sequencing and BLAST showed that the molecular weight of the DNA of each candidate probiotic bacterial isolates showed different molecular weight which candidate A isolates has $2038 \mathrm{bp}, \mathrm{B} 1500 \mathrm{bp}, \mathrm{C} 1493 \mathrm{bp}, \mathrm{D}$ 1491 bp, E 1487 bp, F 1490 bp, G 1491 bp, H 1486 bp, I 1474 bp, J 1488 bp and K 1486 bp.

System BLAST (Basic Local Alignment Search Tool) via the website http//www.ncbi.nlm.nih.gov/ could find the name of the species, the percentage of DNA sequence homology. They were submitted into Gen Bank to gain access number and get the code DNA. Results of BLAST can be seen in Table 2.

Results of BLAST showed that only A bacterial Isolate has closer charecteristic with species of Bacillus meanwhile the other species only has genus charecteristic. A bacterial isolates have homology $99 \%$ on the bacteria BDU4 strains Bacillus sp., whereas 10 bacterial isolates only have between $91-96 \%$ homology level so that only 10 isolates of bacteria has closer relation to the genus Bacillus. According to Handayani (2008) 16S rDNA sequence homology of each bacterial isolates in Gen Bank database can be seen that there is no sequence identical bacterial 16S rDNA.

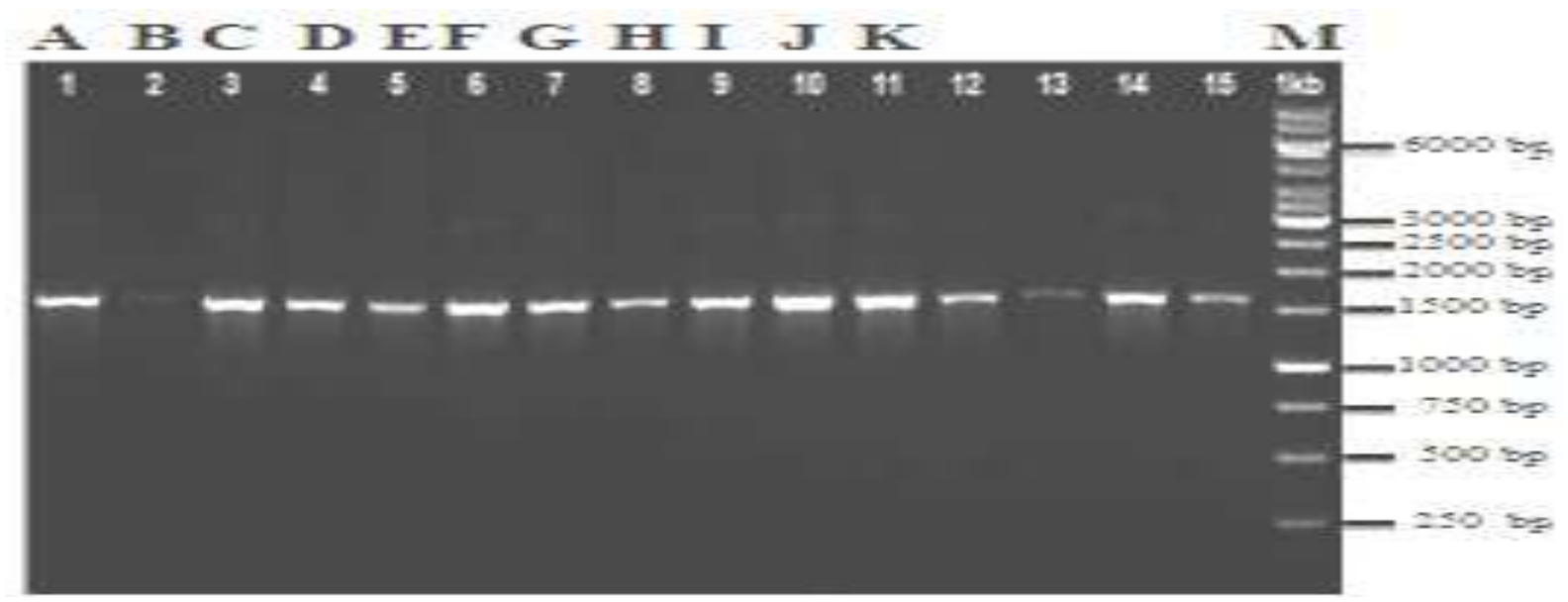

Figure 1. Results Purification of Bacterial DNA

Description:

A - K : Bacterial Isolates

M : Marker

Table 2. BLAST and Submit result into Bacterial Gen Bank DNA from digestive track of Giant Prawns (Macrobrachium rosenbergii, de Man)

\begin{tabular}{|c|c|c|c|c|}
\hline Isolates Bacteri & Bacteria & Strain & Acces Code & Homology $(\%)$ \\
\hline $\mathbf{A}$ & Bacillus sp. & BDU4 & JX847609 & $99 \%$ \\
\hline B & Unculture bacterium B & & KF256130 & $94 \%$ \\
\hline $\mathrm{C}$ & Unculture bacterium $C$ & & FJ217203 & $94 \%$ \\
\hline $\mathrm{D}$ & Unculture bacterium D & & FJ217203 & $92 \%$ \\
\hline $\mathrm{E}$ & Unculture bacterium E & & HM480354 & $93 \%$ \\
\hline $\mathrm{F}$ & Unculture bacterium F & & HM367740 & $93 \%$ \\
\hline G & Unculture bacterium $G$ & & HM480354 & $91 \%$ \\
\hline $\mathrm{H}$ & Unculture bacterium $H$ & & FJ217203 & $90 \%$ \\
\hline I & Unculture bacterium I & & AM778998 & $96 \%$ \\
\hline $\mathrm{J}$ & Unculture bacterium J & & DQ105975 & $95 \%$ \\
\hline $\mathrm{K}$ & Unculture bacterium $K$ & & HM480354 & $93 \%$ \\
\hline
\end{tabular}


Hagstrom et al. (2000) stated that the bacterial isolates have $16 \mathrm{~S}$ rDNA sequence formula more than $97 \%$ may represent the same species. The formula of sequences between $93 \%$ $-97 \%$ can represent identity in the genus level but different in the species level.

The Results from the Gen Bank was found out high homology bacteria in A Isolate bacterial while others below 97\%. They were supposed that these bacteria have not been found out in Gen Bank. For more details, we can see in the phylogenetic trees (Figure 2).

Phylogenetic tree (Phylogenetic trees) makes connecting the branching points (nodes), which is a unit of taxonomy, such as species or genes, while the roots of the tree are the points as ancestors to the whole organism that is being analyzed (Radjasa, 2006). Alignment sample sequences from Gen Bank's data base were done by using the program Clustal $\mathrm{X}$. Program NJ in the Clustal X $100 \mathrm{x}$ bootstrap level was used to get Filogenetik Tree, then the results can be seen in the Treeview program. Phylogenetic tree is useful to show the phylogenetic from all species based on molecular characteristics in both species in different species and strains in the same species as can be seen in Figure1.

\section{Discussion}

Eleven isolates were found in the digestive prawns which is the only one isolate that already has similarities with world gen Bank. It is A isolates. Because it has $99 \%$ homology. Philogenetik tree has nodes Bacillus thuringiensi 10000 (Figure 2). Similarly, isolates $H$ that have nodes; 8551, lower than the rate of homologous isolates of A. According Baehaki and Rinto (2011), Bacillus sp. is one type of bacteria which has the ability to produce proteases. Protease is one of three commercial enzyme group traded as biological catalysts. Protease was used in various industrial applications of food and non - food. One non - food industries that utilize protease is biodeterjen industry. Bacillus sp is a proteolytic bacteria that can break down proteins into amino acids (Ryan et al., 2012). This is used to multiply, thus increasing the feed protein and lower crude fiber (Ryan et al., 2012). In addition, these bacteria are also capable of describing disaccharides and polysaccharides into simple sugars that is able to producet pectin, it is a complex carbohydrate (Ryan et al., 2012).

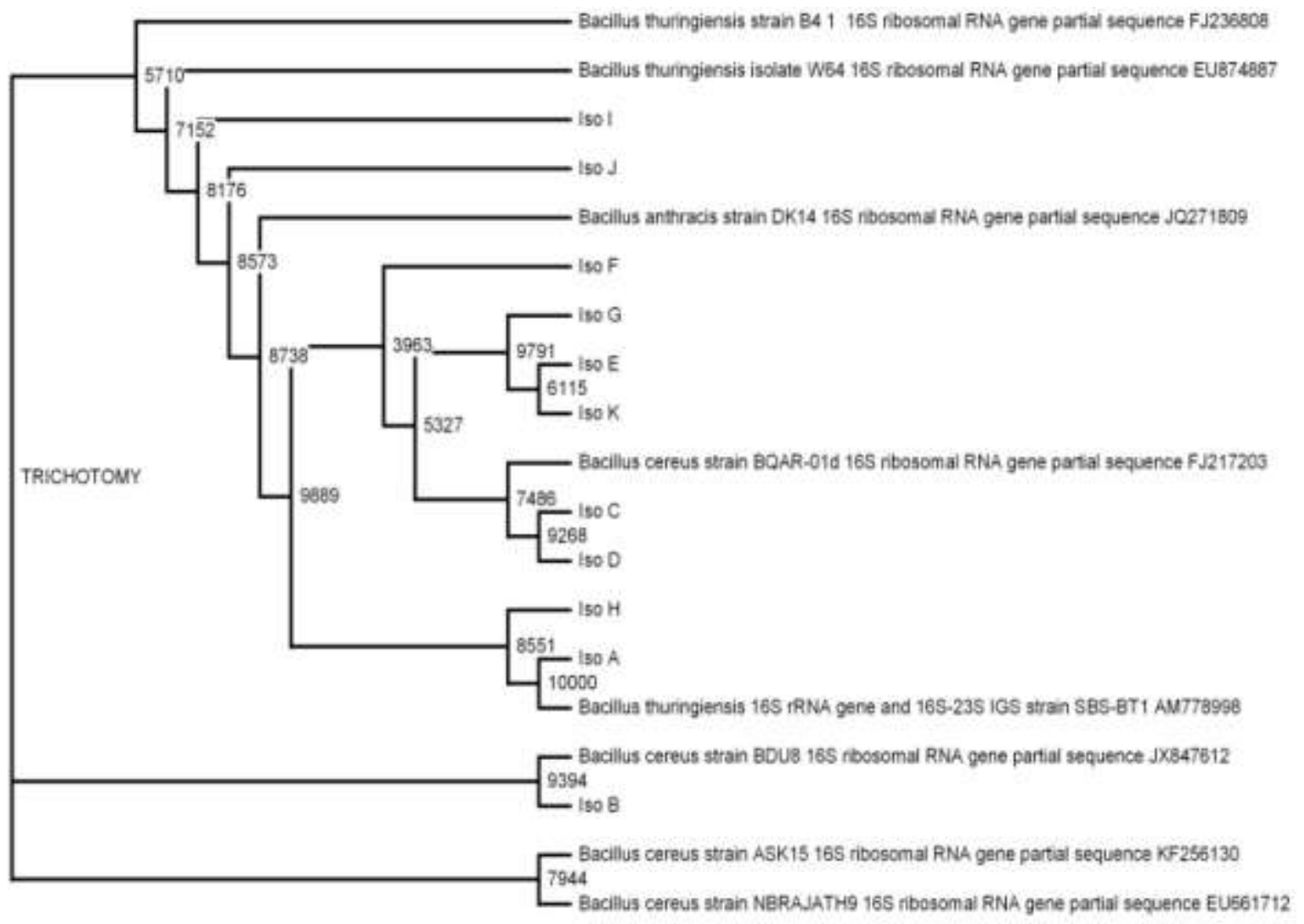

Figure 2. Phylogenetic Trees AK Bacterial Isolates 
Sequencing and and philogenetic trees result were not found the similaraty bacterial in the world Gen Bank. Isolate B is thought to be a new species because it is based on the nearest blast analysis has only $94 \%$ homology (Table 2) while philogenetik tree distantly related to bacillus subtilis which has 9394 nodes.

Bacillus subtilis is a Gram positive, like wood, can be grown in aerob conditions, anaerob, free-living or pathogenic. Several Bacillus species produce extracellular enzymes such as protease, lipase, amylase, and cellulase which can aid digestion in animals (Wongsa and Werukhamkul, 2007). Types of Bacillus (B. cereus, B. clausii and B. pumilus) included in five commercial probiotic products for colonization, immunostimulasi, and antimicrobial activity (Duc et al., 2004).

B. subtilis has the ability to form endospores protective bacteria which gives the ability to tolerate extreme circumstances. B. subtilis is not considered a human pathogen can contaminate food though, but rarely causes food poisoning. B. subtilis produces the proteolytic enzyme subtilisin. $B$. subtilis spores can live in the extreme heating that is often used to cook food, and is responsible for causing a sticky consistency. The advantages of these bacteria are able to break large amounts of antibiotics out of the cell (Susanti, 2003).

Isolates C and D isolates which each of them had the highest levels homologous only $94 \%$ and $92 \%$, so it is also believed to be a new species yet to be discovered in the world's gen banks are believed to be the same species if they have had the similarity of $97 \%$. From the analysis of second tree philogenetic, the isolates relates Bacillus cereeus which has 7486 nodes (Figure 1). It has the similarity with E, F, G, I, J, and K isolated but only have the different nodes from each other and all of them have the similarity with the bacterium Bacillus cereeus.

Bacillus cereus is a member of the genus Bacillus which was first isolated in 1969 from blood and pleural fluid of pneumonia patients. Bacillus cereus has some morphological characters including: Gram-positive cells in width from 0.9 to $1.2 \mu \mathrm{L}$ and a length of $3-5 \mu \mathrm{L}$. Motility positive, spore elipsoidal, central or paracentral, rarely out of the sporangia spores. Not like capsule, usually appears in the form of long chains of type R. The form irregular colonies, opague sometimes like waxy. Moderate turbidity is formed in liquid medium (ABIS encyclopedia, 2009). Type of Crustacea
Crustacea in the sea such as windu shrimp (Penaeus monodon) were found by Rume et al. (2012) there are three types of bacteria of the genus Bacillus, Lactobacillus and Staphylococcus. Species of Lactobacillus paracasei sp. paracasei is found from Balon Parents digective (Sarkono et al., 2010).

Eleventh candidate probiotics bacteria of Bacillus type is expected to be used to improve productivity in the field of fish and shrimp farming is good for the growth and repair the capacity of field.

\section{Conclusions and Recommendations}

Based on the results of studies, it is known that bacteria were isolated and identified from the digestive Giant prawns (Macrobrachium rosebergii) are all derived from the bacterium Bacillus genus and species of the isolates were approaching that of a bacterial isolates to the species Bacillus sp. While the tenth isolates believed to be a new species because it has not been registered in Gen Bank and thought to be bacteria from Riau Indonesia. It is believed to be due to homologous highest level reached only $94 \%$.

To next study is expected to find a primary or secondary metabolite content of what have all eleven bacteria which is expected to improve the quality of fish and shrimp farming in Indonesia.

\section{Acknowledgements}

Appreciation and thanks are due to the Head of the Research Institute of University of Riau and his staff. For its cooperation in research activities in the Institute for Biotechnology Serpong, Tangerang Banten. Thanks is also dedicated to all those who have given their criticism and suggestions in the preparation of research reports. This study is part of the DIKTI Competence Grant in Year 2013/2014.

\section{References}

ABIS encyclopedia. 2009. Bacillus cereus . http://www.tgw1916.net/ABIS/ encyclopedia . html . accessed : February 20, 2010.

Anggriani, R., Iskandar, and A. Taofiqurohman. 2012. Effectiveness addition of Bacillus sp. Results Isolation of Gastrointestinal Feeding Catfish in Commercial Against Seed Survival and Growth of Red Tilapia (Oreochromis niloticus). Journal of Fisheries and Maritime 
Affairs. Faperika. Padjadjaran University. Bandung. 75-83.

Baehaki, A. and B.A. Rinto. 2011. Isolation of Bacteria and Proteases Karekterisasi Indralaya Swamp Land, South Sumatra. J. Technology and the Food Industry, XXII (1) : 10-16.

Duc, L.H., H.A. Hong, T.M. Barbosa, A.O. Henriques, and S.M. Cutting. 2004. Characterization of Bacillus probiotics available for human use . J. Appl. Environ. Microbiol., 70 (4) : 2161-2171.

Feliatra, I. Efendi, and E. Suryadi. 2004 . Isolation and Identification of Probiotic Bacteria Tiger Grouper (Ephinephelus fuscogutatus) In Fish Feed Efficiency Efforts. Indonesian Journal of Natur, ISSN 1410-9379.

Hagstrom, A.J.F. Pinhassi, and U.L. Zweiefel. 2000. Biogeoghraphycal Marine Diversity Among Bacretioplankton . Aquatic Microbial Technology, $21: 231-244$.

Irianto, A. 2003. Probiotics Aquaculture. Gadja Mada University Press. Yogyakarta. 125 p.

Radjasa, K.O. 2006. Psychrotrophic Rapid Grouping of Marine Bacteria Using Fragent Restriction
Length Polymorphism Analysis of PCRAmplified 16S. Internet. http://www.karnaradjasa.com.

Rume, I.M., A. Rantetondo, and G. Latama. 2012. Isolation of Intestinal Bacteria Probiotics Tiger Shrimp And Their Applications in Effort to Control the Vibrio harveyi infecting larvae Tiger Shrimp (Penaeus monodon Fabricius). Journal of Hasanuddin University.

Sarkono, Faturrahman, and Y. Sofyan. 2010. Isolation and identification of lactic acid bacteria from parent abalone (Haliotis asinina) as a potential probiotic candidates. Biotechnology, 7 : 99-106.

Susanti, V.H. 2003. Isolation and Characterization of Protease from Bacillus subtilis 1012M15. University of March, Surakarta.

Wongsa, P. and P. Werukhamkul. 2007. Product Development and Technical Service, Biosolution International. Thailand : Bangkadi Industrial Park 134/4.

Yulvizar, C. 2013. Isolation and Identification of Probiotic Bacteria on Rastrelliger sp. Biospecies, 6 : 1-7. 